\title{
Geopolitika ir informacinis karas: Rusijos požiūris
}

\begin{abstract}
Straipsnyje pristatomas Rusijos mokslininku požiūris i geopolitikos transformaciją informacijos amžiuje. Išryškinami galios ir erdvès sampratų pokyčiai, kurie sukūrè sąlygas informacinei geopolitikai tapti aktualia mokslinès analizès problema. Aptariamas informacinio karo, kuris Rusijoje suvokiamas kaip šiuolaikinių geopolitinių strategijų igyvendinimo įrankis, reiškinys. Iškeliama tradicinių manipuliavimo technikų taikymo ir „mediageninių“" krizių dramaturgijos grèsmè. Pristatoma valstybės informacinés kultūros, kuri atlieka šiuolaikinès visuomenès apsaugos nuo tokių informacinių atakų funkciją, samprata. Informacinio karo tyrimuose ir politikos praktikoje pastaruoju metu ryškejja tendencija informacinio saugumo problemas spręsti tradiciniais draudimu ir ribojimu būdais. Toks požiūris netinka atviroms demokratinèms visuomenėms, todèl straipsnyje siūlomi alternatyvūs informacinio saugumo sprendimo būdai.
\end{abstract}

\section{Ivadas}

Informacinè revoliucija, paraleliai vykstantys globalizacijos ${ }^{1}$ bei skirtumu ịtinkinimo, arba internacionalizacijos ${ }^{2}$, procesai transformuoja šiuolaikinius tarptautinius santykius - jie plètojasi globalioje informacinëje erdvejje ${ }^{3}$, kurioje formuojasi nauji politinio bendradarbiavimo, konkurencijos ar tarptautinès sistemos subjektu konflikto principai. Politiniai procesai šioje erdvèje vyksta realiu laiku, mažėja geografinių barjerų reikšmè, kinta geopolitikos samprata. Lietuvai siekiant būti aktyviu tarptautinių santykių veikëju, norint sẻkmingai igyvendinti užsienio politikos tikslus, būtina suvokti, kaip šiuolaikinè geopolitika yra suvokiama Rusijoje - valstybejje, kuri darè ir darys didžiulę įtaką Lietuvai.

Lietuvoje ypač populiarus geopolitinis diskursas. Aktyviai vystoma

\footnotetext{
* Nerijus Maliukevičius - Vilniaus universiteto Tarptautinių santykių ir politikos mokslų instituto doktorantas. Adresas: Vokiečiu g. 10, 01130 Vilnius, tel. 25141 30, el. paštas: maliukevicius@yahoo.com.

${ }^{1}$ Globalizacija - tai pasaulinis informacinių technologijų standartų, valdymo ir gamybos šablonų isitvirtinimas bei socialinių ir politinių struktūrų, kultūrų ir vertybiu supanašèjimas, skatinantis bendrų institucijų bei režimų kūrimąsi.

${ }^{2}$ Internacionalizacija - tai intensyvejjantys saryšiai tarp skirting $u$ tarptautinių santykių subjektų sujungiantys juos i vieną bendriją, kurioje išsaugomas tautinis bei kultūrinis savitumas.

${ }^{3}$ Globali informacinè erdvè - tai tarpusavyje sąveikaujančios arba konfliktuojančios valstybès, institucijos, kultūros ar religijos, susijusios informaciniais, telekomunikaciniais bei žiniasklaidos sąryšiais, kurių neriboja geografinès ar laiko kliūtys.
} 
Raimundo Lopatos ir Vytauto Žalio pristatyta geopolitinio kodo samprata ${ }^{4}$. Svarbu, kad šie tyrimai vykdomi Lietuvos kaimyniu geopolitiniu strategiju kontekste $^{5}$. Tačiau jiems trūksta informacinès dimensijos, kuri yra centriné Rusijoje plètojamos informacinès geopolitikos ašis.

Moderniose geopolitikos interpretacijose Rusijoje išsiskiria naujas požiūris i geopolitinès galios ir erdvès sampratas. Informacinès geopolitikos ekspertai Igoris Panarinas ${ }^{6}$ bei Andrejus Manoilo ${ }^{7}$ pabrèžia švelniosios galios, kuri remiasi informaciniais bei žiniasklaidos ištekliais, reikšmę šiuolaikiniams tarptautiniams santykiams. Globali informacinė erdvé - tai naujas geopolitikos laukas, kuris skiriasi nuo klasikineje geopolitikoje dominavusio topografinio pasaulio vaizdo. Kai kurie Rusijos ekspertai (Sergejus Rastragujevas ${ }^{8}$, Georgijus Počepcovas ${ }^{9}$ ) šioje erdvèje siūlo naudoti informacinio karo priemones.

Informacinis karas šiame kontekste tampa papildomu užsienio politikos igyvendinimo ịrankiu, o teisiniai, moraliniai ar etiniai tokios veiklos aspektai tampa antraeiliais. Šio reiškinio analizė yra ypač aktuali socialiniams mokslams, siekiantiems kuo objektyvesnio socialinio pasaulio vaizdo, nes pats informacinis karas turi kardinaliai priešingą tikslą - realybès iškraipymą.

\section{Geopolitikos transformacija}

\section{1. Šiuolaikiniai galios svertai}

Šaltojo karo pabaiga, anot Iano Clarko, paskatino nauju galios formu atsiradimą ${ }^{10}$. Susana Strange atkreipia dèmesį, kad globalizacijos paveiktoje modernioje tarptautinëje aplinkoje valstybės apskritai praranda monopoli i galią ${ }^{11}$. Vis didesnę įtaką igauna didžiosios korporacijos, nevyriausybinės organizacijos ir kiti nevalstybiniai subjektai. Kiti autoriai akcentuoja suvereniteto fragmentaciją. Patrickas Tyrrellas prognozuoja, kad šalia valstybės suvereniteto globalioje informacinëje erdvèje formuosis lingvistiniai, religiniai ar kultūriniai

\footnotetext{
${ }^{4}$ Lopata R., Žalys V. „Lietuvos geopolitinis kodas“, Politologija Nr. 1 (6), 1995, p. 13-21.

${ }^{5}$ Laurinavičius Č., Motieka E., Statkus N., Baltijos valstybiu geopolitikos bruožai: XX amžius, Vilnius: Lietuvos istorijos instituto leidykla, 2005.

${ }^{6}$ Панарин И., Технология информационной войны, КСП+, 2003; Панарин И., Информационная война и мир. Олма-Пресс, 2003; Панарин И., Информациионная война и дипломатия, Городец, 2004. 7 Манойло А. В., Государственная информационная политика в особых условиях, Москва, 2003, http://www.psyfactor.org/lib/psywar27.htm, 20061102.

${ }^{8}$ Расторгуев С. П. Информационная война, Радио и связь, 1999, http://www.bookap.by.ru/psywar/infowar/oglav.shtm, 200611 02;

Расторгуев С. П. „Инфицирование как способ защиты жизни“, 1996, http://www.koob.ru/rastorguev/ virus, 20061102.

${ }^{9}$ Почепцов Г. Г., Информационные войны, Киев: Ваклер, 2000.

${ }^{10}$ Clark I., Globalization and Fragmentation: International Relations in the Twentieth Century, Oxford University Press, 1997, 196.

${ }^{11}$ Strange S., The Retreat of State: the Diffusion of Power in the World Economy, Cambridge University Press, 1996.
} 
suverenitetai, nebūtinai sutampantys su valstybių teritorinėmis ribomis ${ }^{12}$. Kyla klausimas, kas taps šių naujų erdvių suverenais?

Robertas Keohane ir Josephas Nye įsitikinę, kad šiais suverenais išliks valstybės, jei sėkmingai prisitaikys prie informacinio amžiaus realijų ir užsitikrins švelniosios galios kontrolę $e^{13}$. Švelniają galią šie autoriai apibrèžia „kaip galimybę pasiekti norimus rezultatus, nes kiti siekia to, ko sieki tu“"14. Tokia galia ryškiai skiriasi nuo Šaltojo karo metu dominavusios tradicinès karinès galios.

Būtent švelniosios galios koncepcija tampa viena iš pamatiniu informacinès geopolitikos sampratų. XXI a. pagrindiniai tokios galios ištekliai bus informacija, informacinès technologijos bei žiniasklaidos priemonès. Dar Jamesas Burnhamas atkreipè dèmesį i tai kad, „industriniame amžiuje galia buvo sutelkta didžiojo kapitalo savininkų rankose, o poindustrinëje eroje galia pereina į vadybininkų ir administratorių rankas ${ }^{\prime 15}$. Sie naujieji galingieji - tai informacijos ir žinių vadybininkai. Frankfurto mokyklos pasekejai dar praeito amžiaus viduryje juos vadino "viešosios nuomonès vadybininkais “ ${ }^{\text {“16. }}$.

Užsienio politikos efektyvumas ateityje vis labiau priklausys nuo to, kiek patrauklios ir populiarios bus valstybės propaguojamos idejos. Formuodamos koalicijas bei užsitikrindamos paramą tarptautinėms iniciatyvoms, valstybės turès pasitelkti ryšiu su visuomene arba politikos marketingo principus ${ }^{17}$. Galima teigti, kad šiuolaikinejje tarptautinèje sistemoje keičiasi galinguju bruožai. Šiuos pokyčius galima iliustruoti chrestomatiniu Niccolo Machiavellio elitų skirstymu ị "lapių“ ir "liūtų“ tipus, kurị savo teorijoje naudoja Vilfredas Pareto:

\footnotetext{
${ }^{12}$ Tyrrell P. „The Information Revolution“, Netherlands Annual Review of Military Studies (NLARMS): Information Operations, ed., Bosch J. M. J., Luiijf H. A. M., Mollema, Haveka A. R., 1999, p. 73.

${ }^{13}$ Keohane R. O., Nye J. S. „Power and Interdependence in the Information Age“, Foreign Affairs Nr. 5 (77), 1998, http://www.ksg.harvard.edu/prg/nye/power.pdf, 20061102.

${ }^{14}$ Ten pat.

${ }^{15}$ Rush M., Politics and Society: an Introduction to Political Sociology. Harvester Wheatsheaf, 1992, p. 65 .

${ }^{16}$ Macnamara J. R., „,Mass Media Effects: a Review of 50 Years of Media Effects Research“, CARMA White paper, 2003, p. 2, http://www.masscom.com.au/Downloads/Media_Effects_(A4).pdf, 20061102.

${ }^{17}$ Henneberg S. C., „Political Marketing Theory“, Working Paper Series, University of Bath, 2004, http:// www.bath.ac.uk/management/research/pdf/2004-01.pdf, 20061102.
} 
Lentelè 1. Machiavellio elito tipų bruožai Pareto teorijoje

\begin{tabular}{|l|l|}
\hline \multicolumn{1}{|c|}{ Lapès } & \multicolumn{1}{c|}{ Liūtai } \\
\hline Inteligentiški, & Linkę konfrontuoti, \\
manipuliatoriai, & ryžtingi, \\
turintys lakią vaizduotę, & principingi, \\
siekiantys konsensuso, & patikimi, \\
lankstūs, & nekantrūs, \\
atkaklūs, & negailestingi, \\
ištvermingi. & nelankstūs. \\
\hline
\end{tabular}

Šaltinis: Rush M., Politics and Society: an Introduction to Political Sociology. Harvester Wheatsheaf, 1992, p. 64 .

Pareto iškeltas šių skirtingų elitų kovos ir kaitos principas pasireiškia ir tarptautinëje erdvëje: Šaltojo karo metu tarptautiniuose santykiuose dominavusi "liūtų" tipą ir jam būdingus bruožus keičia informacijos amžiaus „lapès", t. y. valstybès, kurios įtvirtindamos savo valią sugeba efektyviai manipuliuoti informacija, politikoje pasitelkia įtikinèjimą, lanksčiai, bet atkakliai siekia savo politikos, vertybių bei kultūros populiarumo.

Šiuolaikinei geopolitikai socialiniai-komunikaciniai ištekliai (TV kanalai, radijas, spauda) tampa tokie pat svarbūs kaip ir natūralieji ištekliai (nafta, dujos). Telekomunikacijų rinkų kontrolè igauna tokią reikšmę, kad valstybiu vidaus rinkose ir globalioje informacinejje erdvëje pasireiškia aršios ekonominès-politinès kovos dèl žiniasklaidos kontrolès. Vygantas Žylè atkreipia dèmesį į tai, kad „pati jẻga vis labiau igauna komunikacinių struktūru pavidalą, kuris ir yra beveik vienintelè tos jègos raiška"18.

\subsection{Globali informacinè erdvė - naujas geopolitikos laukas}

Informacijos amžiuje kinta ne tik galios, bet ir erdvės suvokimas. Frankas Websteris, analizuodamas informacinès visuomenès fenomeną, pabrèžia jo daugialypiškumą ir skiria kelis šiuolaikinei geopolitikai aktualius aspektus:

- technologini, kuris pabrėžia informacinių technologijų paplitimo mastą ir jų eksploatavimo kaštų mažèjimo tendenciją;

- ekonomini, kuris akcentuoja žinių ekonomikos svarbą šiuolaikiniu visuomenių konkurencingumui;

- profesini, kuris pabrèžia darbo vietų informacijos sferoje pasiūlos augimą;

- erdvini, kuris akcentuoja globalų informacinių tinklų paplitimą, keičianti geografinių barjerų ir laiko reikšmę;

- kultūrini, kuris informacijos kūrimo ir sklaidos procese pabrèžia

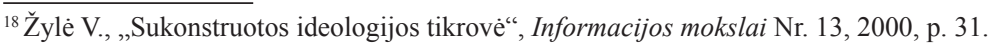


tarpininkų vaidmeni, taip pat pačios informacijos gausẻjimo tendenciją bei iš to kylančias socialinès realybès interpretacijos problemas ${ }^{19}$.

Būtent erdvinis ir kultūrinis informacinès visuomenès aspektai sudomino informacinès geopolitikos atstovus. Dar Alvinas Toffleris atkreipé dèmesi, kad kapitalistinès visuomenès, žengdamos i̇ postindustrinę era, "kuria informacines erdves, kuriose pranešimai bei žinios paskirstomi taip pat efektyviai, kaip produktai ir natūralūs ištekliai industriniame amžiuje ${ }^{\prime \prime 20}$. Formuojasi nauja erdvè, kuri yra globalizacijos padarinys. Websteris teigia, kad globalizacija - „tai rinku, valiutu, korporacinių organizaciju jungimasis “21. Šį reiškinị plačiau galima apibrěžti kaip pasaulinį informaciniu technologijų standartu, valdymo ir gamybos šablonu ịsitvirtinimą bei socialinių ir politinių struktūru, kultūrų ir vertybių supanašèjimą. Analizuojant informacinę erdvę globalizacijos kontekste yra pabrèžiamas pasaulinis, visuotinis, šios erdvės mastas. Tačiau globali informacinè erdvė nèra vienalytė. Egzistuoja atskiros ne tik valstybiu, bet ir kultūru, religiju informacinès erdvès. Taigi globalią informacinę erdvę reikia analizuoti ir skirtumų įtinklinimo, arba internacionalizacijos, kontekste. Šị procesą galima apibrěžti kaip intensyvëjančius sąryšius tarp skirtingų tarptautinių santykiu subjektu, sujungiančius juos į vieną bendriją, kurioje išsaugomas tautinis, kultūrinis ar religinis savitumas.

Pabrěžiant ne tik bendrumus, bet ir skirtumus, atkreipiamas dėmesys ị tai, kad santykių spektras šioje erdvëje gali svyruoti nuo bendradarbiavimo iki konflikto, atitinkamai gali kisti priemonės, naudojamos tikslams pasiekti.

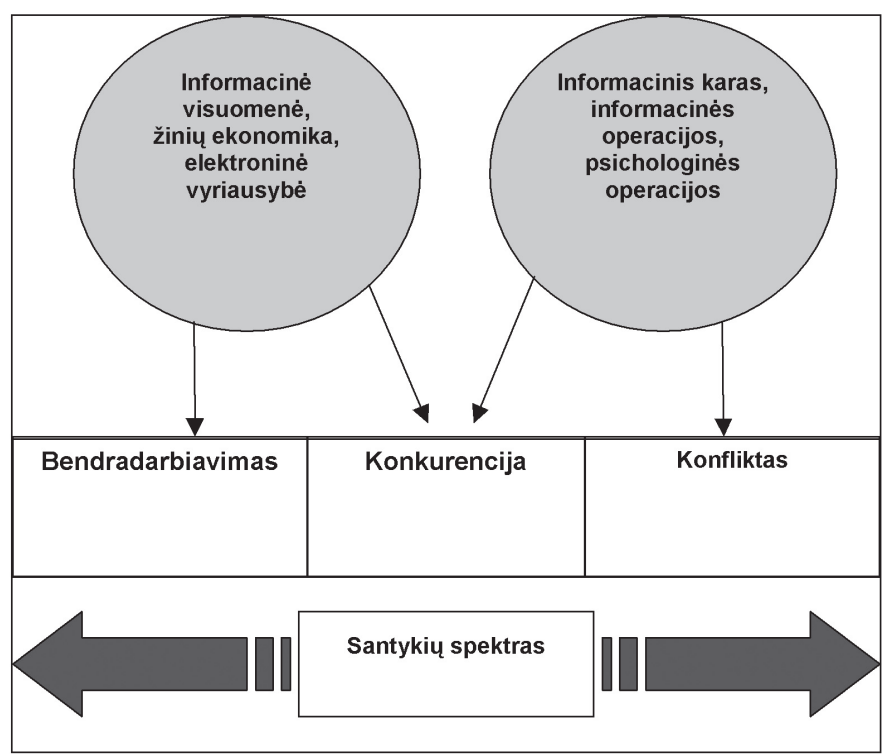

Schema 1. Santykių globalioje informacinèje erdvèje spektras ir naudojamos priemonès.

\footnotetext{
${ }^{19}$ Webster F., Informacinès visuomenés teorijos, Vilnius, Poligrafija ir informatika, 2006, p. 14-27.

${ }^{20}$ Toffler A., The Third Wave, Bantam Books, 1980, p. 35.

${ }^{21}$ Webster (išnaša 19), p. 75.
} 
Šiuolaikinès geopolitinio balanso paieškos vyksta globalioje informacinëje erdvèje (GIE) 22 (̌̌r. Schemą 2). Šios erdvès sampratą pristatė Kanados saugumo ir karo studijų bendruomenės atstovai ${ }^{23}$. Tačiau juos domino, kaip ši erdvẻ daro įtaką moderniems kariniams konfliktams. Kiti autoriai, atsiriboję nuo karinių aspektu, pateikè savo globalios informacinės erdvès vizija, sudarytą iš tokių elementư $u^{24}$ :

- informaciniu sistemu, i kurias įeina komunikacijos tinklai (informacijos persiuntimo priemonės), telekomunikacijos transliavimo technologijos (informacijos pristatymo priemonès) ir programinè ịranga (vartotojui patogūs informacijos apdorojimo ir pateikimo sprendimai);

- informacijos;

- žmonių.

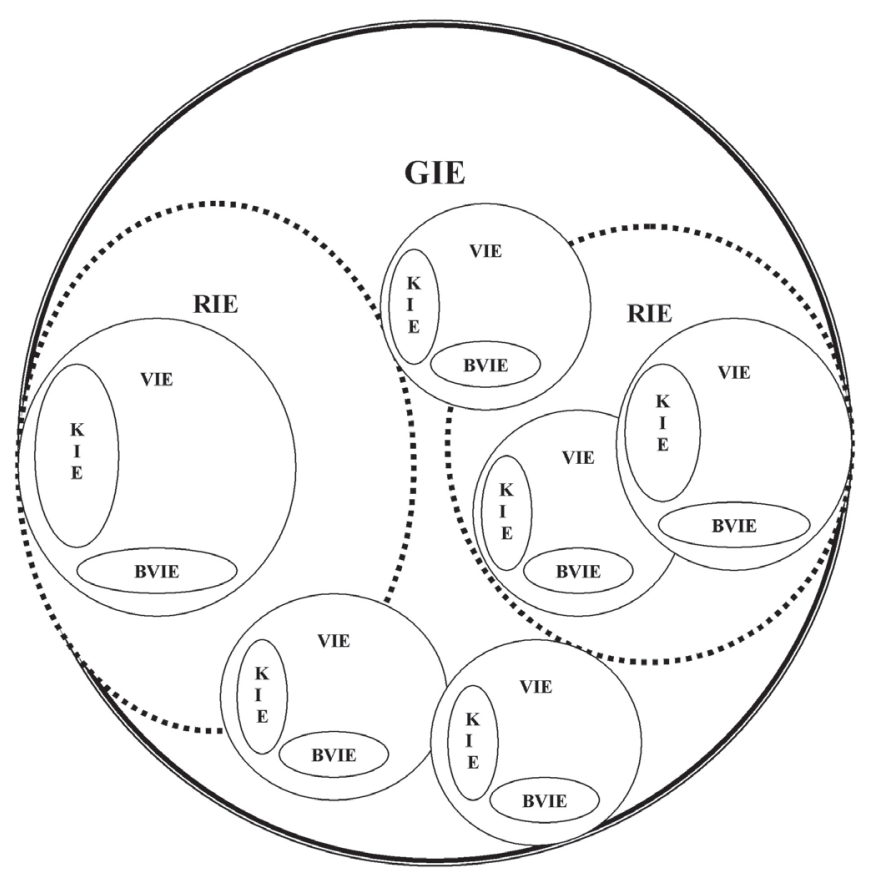

Šaltinis: Adaptuota schema, žr. Jones A., Gerald L., Kovacich, Perry G., Luzwick, Global Information Warfare: How Businesses, Governments, and Others Achieve Objectives and Attain Competitive Advantages. Auerbach Publ, 2002, p. 56.

\section{Schema 2. Globali informacinè erdvè ${ }^{25}$}

${ }^{22}$ Vartojami global information environment (angl.) arba global information infrastructure (angl.) terminai [N. M.].

${ }^{23}$ Garigue R., Romet T., „Information Warfare and the Canadian Forces“, National defense, May 1996, http://www.iwar.org.uk/iwar/resources/canada/iw_\&_cf.pdf, 20061102.

${ }^{24}$ Jones A., Gerald L., Kovacich, Perry G., Luzwick, Global Information Warfare: How Businesses, Governments, and Others Achieve Objectives and Attain Competitive Advantages. Auerbach Publ, 2002, p. 56.

${ }^{25} \mathrm{GIE}$ - globali informacinè erdvė; RIE - regioninè informaciné erdvé; VIE - valstybès informaciné erdvé; BVIE - bazinè valstybės informacinè erdvé; KIE - karinè informacinè erdvè. 
Žiniasklaidos erdvès pokyčius analizavęs Ivanas Zassourskis teigia, kad tradicinė Gutenbergo visata elektroninès žiniasklaidos ir interneto dėka išsiplètė iki globaliu mastų ir sujungè valstybes, kultūras ir religijas į vieną informacinį tinklą ${ }^{26}$. Johnas Arquilla ir Davidas Ronfeldtas tokią erdvę pavadino „noosfera“27. I šią erdvę, ju manymu, patenka ir virtuali (cyberspace - angl.), ir žiniasklaidos erdvès ${ }^{28}$. Rusijos informacinès geopolitikos ekspertas Panarinas taip pat vartoja šį terminą. Jam "noosfera" - tai savotiška pseudoreali erdvė, kurioje galima modeliuoti Rusijos geopolitines koncepcijas, turinčias realiu politiniu pasekmių ${ }^{29}$.

Globali informacinė erdvè (GIE) - tai tarpusavyje sąveikaujančios arba konfliktuojančios valstybiu informacinès erdvès (VIE) bei kultūriniu, religiniu ar politiniu pagrindu susiformavusios regioninès informacinès erdvès $(\mathrm{RIE})^{30}$, kurios susijusios informaciniais, telekomunikaciniais bei žiniasklaidos sąryšiais. Bazinė valstybės informacinè erdvė (BVIE) - tai šerdis, nuo kurios apskritai priklauso valstybės egzistavimas. Karinių konfliktų metu ypatingą svarbą igauna ir valstybės karinės informacinès erdvės (KIE) apsauga. Rusijos ekspertų ịsitikinimu, valstybės šerdį sudaro ne tik techninès kilmés sistemos, bet ir tos, kurių pagrindas yra socialiniai-psichologiniai sąryšiai:

- valstybės kultūros paveldas, žmonių patriotizmas ir vertybinès nuostatos;

- gebèjimas efektyviai skleisti oficialią Rusijos politiką įvairiais klausimais savo visuomenei ir tarptautinei bendruomenei ${ }^{31}$.

Teigiama ${ }^{32}$, kad šiuo metu 53 pasaulio šalys formaliai deklaravo savo valstybines informacines erdves (VIE) ${ }^{33}$ ir jas analizuoja bei tobulina norėdamos užsitikrinti saugumą bei stabilų jų funkcionavimą.

Informacinès geopolitikos atstovai ypač domisi regioninėmis informacinėmis erdvėmis (RIE). Visos kitos globalios informacinès erdvės sudedamosios dalys turi geografinius valstybinius pamatus, tuo tarpu „regioninės informacinès erdvès pamatas - tai erdvinis kultūros, vertybių, religijos, verslo ịprasminimas “34. Aktyvią informacinę politiką modernioje tarptautinių santykiu erdvëje Arquilla ir Ronfeldtas vadina „noopolitika“"

\footnotetext{
${ }^{26}$ Zassoursky I., „Media and Politics in Russia in the Nineties“, East Political Science Review Nr. 6, 2000, http://www.polito.ubbcluj.ro/EAST/East6/zassoursky.htm, 20061102.

27 Noos - graikų kalba reiškia protą [N. M.].

${ }^{28}$ Arquilla J., Ronfeldt D. F., The Emergence of Noopolitik: Towards An American Information Strategy, RAND Corp., 1999, p. 4.

${ }^{29}$ Панарин, Информационная война и дипломатия, (išnaša 6) p. 176.

${ }^{30}$ Galimi regioninių informacinių erdvių pavyzdžiai: „, Posovietinè erdve “, ,, Europos erdve “, ,, Rytu kultūra “, „Islamo pasaulis “ ir pan. [N. M.].

31 „Доктрина информационной безопасности Российской Федерации“, http://www.scrf.gov.ru/docu-

ments/decree/2000_pr-1895.shtml, 20061102.

32 Jones, Kovacich, Luzwick (išnaša 24), p. 56.

${ }^{33}$ Pavadinimai gali skirtis: national information infrastructure, national information environment (angl.) ir pan. [N. M.]

${ }^{34}$ Jones, Kovacich, Luzwick (išnaša 24), p. 61.

${ }^{35}$ Arquilla, Ronfeldt (išnaša 27), p. 24.
} 
Šiuo atveju posovietinės erdvès terminas Rusijos geopolitikams tampa modernios geopolitinès kovos arena ${ }^{36}$. Tai verčia naujai pažvelgti i tẻvynainiu fenomeną ${ }^{37}$ (rus. соотечественники) ir ju reikalais besirūpinančių steigiamu institucijų veiklą ${ }^{38}$.

\subsection{Nuo klasikinès iki informacinès geopolitikos}

Geopolitika apibrěžiama kaip "galios transformacija erdveje ${ }^{\text {“39. Todèl }}$ galios ir erdvès sampratu pokyčiai verčia susimąstyti ir apie potencialias geopolitikos disciplinos transformacijas. XX a. pradžioje geopolitika tiesiogiai siejosi su politine geografija. Ivyko pagrindiniai geografiniai atradimai, susiformavo išbaigtas pasaulio vaizdas. Todèl prasidejo centrinès ašies, kurios kontrolè valstybei suteiktų didžiausią galią, paieškos. Halfordui Mackinderiui tokia ašimi tapo Eurazijoje ịsitvirtinęs Heartlandas ${ }^{40}$, Alfredas Mahanas manè, kad galią valstybėms suteikia jūrų kontrolè ${ }^{41}$. Šie autoriai suformulavo pagrindinę klasikinès geopolitikos tradiciją - amžiną ginčą tarp jūrinės ir sausumos galių. Prie šio ginčo vẻliau prisijungė Nikolas Spykmanas ir Karlas Haushoferis ${ }^{42}$. Pabrèžtina, kad vienas esminių klasikinès geopolitikos bruožu tapo dichotomijos įtvirtinimas tarptautinëje politikoje: jūros ir sausumos priešpriešą keitė Šiaurès ir Pietu, kapitalistinio ir komunistinio bloku, krikščionybès bei islamo akistata.

Geopolitikos pradininkams būdingas geografinis determinizmas valstybės politiką ir jos raidą įspraudžia į griežtus topografinius rẻmus. Vèlesni klasikinės geopolitikos atstovai suvokè, kad disciplinos ribas keičia technologinė pažanga - taip pradėta svarstyti apie naują kovą dèl galios ore ${ }^{43}$, kosmose ${ }^{44}$. Geopolitikos raidai įtakos turëjo ne tik gilèjantis ir platejjantis fizinio pasaulio pažinimas, bet ir intensyvëjantis kai kuriu geopolitikų dėmesys socialiniam pasauliui. Istorijos, ekonomikos, kultūros bei psichologijos struktūrinè, o kai kuriais atvejais net ir topografinè analizè lèmè tai, kad pradèti kurti civilizacijų, kultūrų ar religijų žemèlapiai. Prie tokių naujujų klasikinių geopolitikos teoriju kartais priskiriami Samuelio Huntingtono ir Franciso Fukuyamos darbai. Nors po Šaltojo karo suklestëjusios civilizaciju konflikto ar liberalaus kapitalizmo pergalès koncepcijos - tai naujoviškas požiūris i geopolitikos problemas, tačiau jos priskiriamos klasikinės geopolitikos srovei: „Kai kurių tarptautiniu

\footnotetext{
${ }^{36}$ Разуваев В. В., Геополитика постсоветского пространства РАН, Ин-т Европы, 1993.

${ }_{37}^{37}$ Панарин И., „Информационная поддержка соотечественников, http://www.panarin.com/, 20061102.

${ }^{38} 2005$ m. kovo mėnesį buvo įsteigta Tarpregioninių ir kultūrinių ryšių su užsienio šalimis valdyba prie

Rusijos prezidento administracijos, kurios vadovu paskirtas Modestas Kolerovas, žr. http://document.

kremlin.ru/doc.asp?ID=027071, 20061102.

${ }^{39}$ Laurinavičius, Motieka, Statkus (išnaša 5), p. 13.

40 Дугин А., Основы Геополитики, Москва: Арктогея, 2000, http://www.geopolitika.ru/geopol1.htm\#3, 20061102.

${ }^{41}$ Ten pat.

${ }^{42}$ Ten pat.

${ }^{43}$ Giulio Douhet, Hugh Montague Trenchard, William (Billy) Mitchell.

${ }^{44}$ E. C., Astropolitik: Classical Geopolitics in the Space Age, Frank Cass Publ., 2002.
} 
santykių analitikų atsakas į šiuolaikinės tarptautinės politikos iššūkius iš esmės neperžengia klasikinės geopolitikos ribu “45.

Šiuolaikiniams klasikinès geopolitikos atstovams ir fizinis, ir socialinis pasauliai yra baigtiniai ir apibrèžti. Jie nepriima kritikų prielaidos, kad tą pasauli, siekdami savo tikslų ir trokšdami galios, kuria atskiri žmonès, visuomenès, nevyriausybinès organizacijos, transnacionalinès korporacijos, žiniasklaidos konglomeratai ir atskiros valstybès. Geografinių atradimų era baigèsi, tačiau socialinè realybė nèra baigtine - ji iš dalies modeliuojama. Informacinè visuomenè disponuoja socialiniais ištekliais, kurie kardinaliai skiriasi nuo industrinëje visuomenëje dominavusių išteklių. Be to, informacinès technologijos ir komunikacijos priemonès sudaro prielaidas peržengti fizinio pasaulio remus ir kurti „media realybę“, aktyviai konstruoti tapatybes, jungtis iz virtualias bendruomenes, kurios nepaiso geografinių barjeru ${ }^{46}$.

Dar XX a. prancūzų geopolitikas Paulis Vidalis de la Blašas, kritikuodamas savo kolegas, pabrèžè, kad geopolitikoje svarbus ne tik geografinis, bet ir žmogiškasis veiksnys. Būtent čia slypi iniciatyva, vertybès, norai bei siekiai, kurie lemia, ar politikoje panaudojamas geografinis faktorius, ar jis ignoruojamas $^{47}$. Anksčiau iš valstybės ar visuomenès kylanti iniciatyva, susidūrusi su nepalankiais politinès geografijos barjerais, bandydavo juos i iveikti pasitelkdama karinę jègą: geriausiu to pavyzdžiu tapo fašistinès Vokietijos siekis kontroliuoti Heartlandą. Tačiau informacinè revoliucija sukuria galimybes politinei žmoniu ar valstybiu iniciatyvai reikštis globalioje informacinejje erdvèje, kur nesutarimai igauna informacinio, o ne karinio (klasikine prasme) konflikto išraišką.

Taigi naujosios geopolitikos atstovams galios transformacija erdveje tai visuomeniu bei valstybiu kova globalioje informacinejje erdvejje pasitelkiant informacinių technologijų ir komunikacijos priemones. Ši erdvè gali būti padalyta ne vien pasitelkus ginklus.

Šiuolaikiniai Rusijos geopolitiniai projektai apima ir vakariečiu (западники - rus.), ir panslavistu, ir Eurazijos didžiosios valstybės vizijas ${ }^{48}$. Jos skiriasi daugeliu aspektu, tačiau visoms būdingas dvejopas idèjinis pamatas. Visų pirma išskirtinas neoimperinis diskursas, kuris gali svyruoti nuo raginimu plèstis tiek į Vakarus, tiek į Pietvakarius iki siūlymų politiškai ir ideologiškai konsoliduoti valstybę, t. y. sẻkmingai išgyventi posovietinį imperijos „,susitraukimo ciklą“ bei koncentruoti galią ir išteklius naujam „ekspansijos ciklui“" ${ }^{49}$. Toks naujos ekspansijos ciklas siejamas ne su tradicinėmis geopolitinės plètros

\footnotetext{
${ }^{45}$ Ališauskas R., „Interneto geopolitika“ in Vaičiūnas Ž., sudar., Geopolitikos akiračiai, Vilnius: Eugrimas, 2004, p. 15.

${ }^{46}$ „Virtualios socialinės bendruomenès“, ,interneto bendruomenès“, ,tinkliniai sociumai“, ,, virtualios koalicijos" jau tapo mokslinių tyrimų objektais, žr. Castelfranchi C., Yao-Hua T., Trust and Deception in Virtual Societies. Kluwer Academic Publ., 2001.

${ }^{47}$ Дугин (išnaša 40 ).

${ }^{48}$ Lopata R., Statkus N., „Empires, the World Order and Small States“, Lithuanian Foreign Policy Review

Nr. 1-2 (15-16), 2005, p. 40.

${ }_{49}^{49}$ „К барьеру: Дуэль Павловского и Белковского“, Интегрум, http://kreml.org/other/82246730, 2006 1102.
} 
vizijomis, o su informacine ekspansija, apie kurią pastaruoju metu aktyviai šneka ir Panarinas ${ }^{50}$. Antra, šiuose projektuose ypatinga reikšmė suteikiama Rusijos stačiatikių bažnyčiai. Būtent religijos aspektas leidžia geopolitikams šnekèti apie „Rusijos civilizaciją" ar Trečiosios Romos perspektyva, kur taip pat pabrèžiamas informacinis lygmuo. Teigiama, kad per paskutinius dešimtmečius bažnyčia buvo atribota nuo žiniasklaidos, todèl jai turi būti grąžinti komunikacijos svertai ${ }^{51}$. Duginas žengia dar toliau ir šiuo metu aktyviai dirba religinëje informacinëje erdvèje $e^{52}$.

Panarinas teigia, kad jis pirmasis suformulavo informacinès geopolitikos koncepciją ${ }^{53}$, kuri i pirmą vietą iškelia kovos dèl informacijos, o ne dèl fizinès teritorijos svarbą. Tačiau daug dėmesio šiems klausimams skiria ir Manoilo. Pastarasis autorius teigia, kad valstybiu informacinès erdvės gali susidurti, bendradarbiauti, konkuruoti. Viena valstybe gali efektyviai skverbtis į kitos erdvę; bet manipuliuoti jos visuomenės nuomone įmanoma tik tuo atveju, kai tarp šių erdviu egzistuoja bendri kodai (kalba, religija, istorinè patirtis ir pan. $)^{54}$. Priešingu atveju įvyksta susidūrimas, kuris gali turèti ekstremaliu išraišku. Manoilo teigia, kad dominavimą geopolitinio oponento informacinejje erdvejje galima užsitikrinti naudojant tokias pagrindines priemones ${ }^{55}$ :

- Užslèpta informacini valdyma vidiniais konkurento politiniais, ekonominiais bei kultūriniais procesais, o tai sukurtu informacinès, ideologinès, ekonominės bei kultūrinės ekspansijos foną ir nulemtų manipuliatoriui naudingus oponento sprendimus.

- Informacine-psichologine agresija, kuri remiasi ekonominiu, politiniu ir diplomatiniu spaudimu. Gruzijos ir Moldavijos vynų blokadą, kurią iki šiol lydi intensyvios informacinès-psichologinès atakos ${ }^{56}$, galima prilyginti šios priemonès panaudojimui.

- Informacini kara, grindžiama ekonomine blokada bei jegos panaudojimo grèsme. Šią priemonę Rusija pasitelkè reaguodama į Gruzijoje ịvykusį Rusijos kariškiu areštą ${ }^{57}$. Be to, ne tik Gruzijoje, bet ir kituose posovietinès erdvès užšaldytuose kariniuose konfliktuose Rusija iki šiol dislokuoja savo karines pajėgas - taip šalia informacinio karo svertų išlaikoma jegos panaudojimo galimybè.

Subtiliai ar agresyviai informacinei ekspansijai ypač palanki technologinė

\footnotetext{
${ }^{50}$ Панарин И, „Евразийская Русь - Информационная Империя“, http://www.panarin.com/comment/465, 20061102.

${ }^{51}$ Павловский Г., „Идеология: Наша информационная доктрина“, http://www.strana.ru/about/02.html, 20061102.

${ }^{52}$ Duginas yra laidos „Vechi“ kūrèjas ir vedèjas religiniame televizijos kanale „Spas, žr. http://vehi.tv ir http://www.spastv.ru, 20061102.

53 Тымчук Д., „Информационная геополитика: от теории до практики“, http://www.panarin.com/comment/249, 20061102.

${ }^{54}$ Манойло (išnaša 7), p. 76.

${ }^{55}$ Ten pat, p. 17.

${ }^{56}$ Žr. naujienų rubriką, „Запрет на ввоз молдавских и грузинских вин и минеральной воды в Россию“, Regnum, http://www.regnum.ru/dossier/833.html, 20061102.

${ }^{57}$ Žr. naujienų rubriką „Обострение отношений между Россией и Грузией“, Regnum, http://www. regnum.ru/dossier/1056.html, 20061102.
} 
valstybės bei psichologinè visuomenės priklausomybė nuo kitos valstybės informacinių ištekliu, o potencialiu įtakos įrankių ir techniku įvairovę galima iliustruoti Renaldo Gudausko suformuluotu informacinių srautų modeliu.

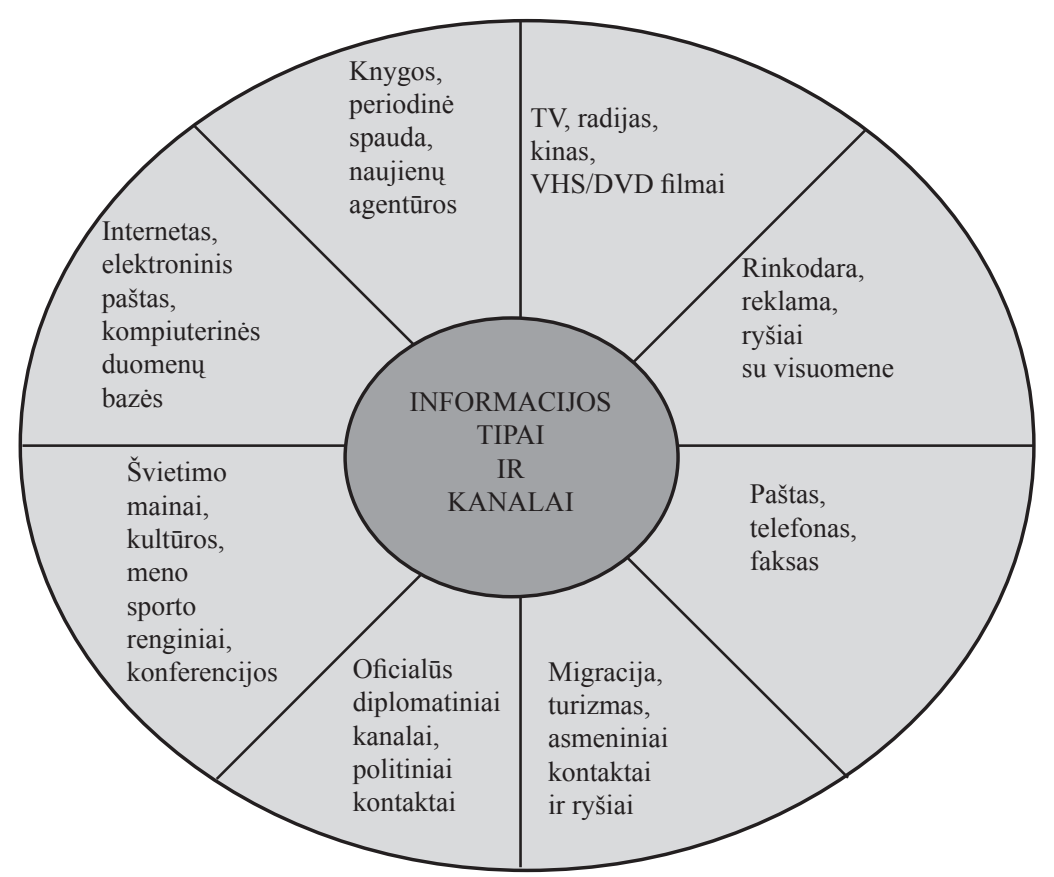

Šaltinis: Adaptuotas Renaldo Gudausko modelis, žr.: Gudauskas R., „Valstybės informacijos strategijos Lietuvos įvaizdžio kūrimo srityje matmenys", Informacijos mokslai Nr. 6(1), 1997.

\section{Schema 3. Informacinių srautų modelis}

Suprantama, tai nėra pilnas informacinių kanalu, priemonių bei įtakos technikų sąrašas, tačiau ši schema iliustruoja didžiuli šio proceso kompleksiškumą. Manoilo pabrèžia, kad kiekvienoje valstybejje egzistuoja nacionalinè informacijos kūrimo ir paskleidimo specifika - tai susiję su kalbiniais, kultūros, religiniais informacijos priemimo ir suvokimo aspektais ${ }^{58}$. Valstybès informacinę erdvę sudaro tik jai būdinga informacinè - telekomunikacinè infrastruktūra, atitinkami informacijos ištekliai, valstybẻje galiojantys telekomunikacijos, žiniasklaidos bei pramogų verslo rinkos principai ir, suprantama, juos reguliuojanti teisinè bazè. Todèl vienas svarbiausių veiksniu, kuris lemia informacinès geopolitikos efektyvuma, - tai kitų valstybių informacinių erdviu gilus ekspertinis išmanymas. Tik ištyrus aplinką parenkamos atitinkamos komunikavimo priemonès, įtikinejjimo technika. Todẻl informacinè geopolitika

$\overline{{ }^{58} \text { Манойло (išnaša 7) }}$, p. 79. 
pabrèžia būtinybę kurti pajėgias kaimyninių informacinių erdvių monitoringo sistemas, pasitelkti šiai veiklai būtinus intelektinius išteklius.

Manoilo siūlo kriterijus ${ }^{59}$, kuriais remiantis būtų galima nustatyti informacinès geopolitikos veiksmingumą ir kuriuos apibendrinti galima taip:

- Sugebëjimas efektyviai kontroliuoti savo informacinės erdvès segmentątai ir informacinés infrastruktūros išsivystymo lygis, ir informacijos bei žiniu kiekybinè ir kokybinè išraiška, ir nepriklausomybė (ekonominè ir kultūrinė) nuo užsienio telekomunikacinių struktūrų bei strateginès informacijos.

- Sugebejjimas užtikrinti savo informacinès erdvès saugumą nuo konkurentu informacinès ekspansijos ir atakų.

- Sugebejjimas plèsti savo įtaką globalioje informacinëje erdvëje, kuris priklauso nuo gebėjimo vykdyti aktyvią informacinę politiką konkurentu atžvilgiu.

- Sugebejjimas informacinei kovai suburti sajungininkus ir formuoti „informacines koalicijas“.

Be to, egzistuoja faktoriai, kurie susilpnina valstybės informacinės erdvės atsparumą informacinei ekspansijai - tai informacinés politikos dezorientacija bei politinių prioritetų ir valstybès vizijos neapibrěžtumas. Tokia situacija kuria sąlygas informacinėms atakoms destabilizuoti politinę situaciją valstybės viduje ir drauge primesti išorinius krizès sprendimo būdus. Suprantama, kad tokie sprendimai turètų tenkinti tik įtaką darančią valstybę. Manoilo savo monografijoje apibendrindamas teigia:

„Informacinè psichologinè ekspansija - tai veikla, kuria siekiama nacionalinių interesų, nekonfliktinio įsiskverbimo į socialinius, kultūrinius visuomenès santykius naudojant metodą. Siekiama nuoseklaus, laipsniško, nuo pačios visuomenès užslëpto socialinių santykiu sistemos keitimo pagal ịtaką darančiojo modelị. Informacinès atakos yra nukreiptos i nusistovejjusią ideologiją, nacionalines vertybes siekiant pakeisti įtaką darančiojo vertybėmis bei ideologinėmis nuostatomis. Tokios veiklos įrankiai - strateginių ištekliu, informacinès-telekomunikacinès struktūros, žiniasklaidos rinkos kontrolè"“60.

Taigi informacinès geopolitikos atstovų požiūris į galią skiriasi nuo šios disciplinos klasikų požiūrio. Pastariesiems galia - tai vadovavimas įvairioms gyvenimo sferoms (politika, ekonomika), kurio ribas nusako politinė geografija, t. y. valstybės teritorija ir sienos. Naujosios geopolitikos atstovai teigia, kad galia - tai vadovavimas informacinei sferai, kuris remiasi žiniomis, informacinès infrastruktūros kontrole bei įtakos viešajai nuomonei technikomis ${ }^{61}$.

\footnotetext{
${ }^{59}$ Ten pat, p. 272.

${ }^{60}$ Ten pat, p. 303.

${ }^{61}$ Попов В., „Коммуникативная и социальная природа и функция власти“, http://www.informanalytic. ru/images/stories/text/popov5.zip, 20061102
} 


\section{Informacinis karas, kaip geopolitinès kovos įrankis}

\subsection{Valstybès informacinè kultūra - šiuolaikinès visuomenès apsaugos mechanizmas}

Geopolitikos klasikas Friedrichas Ratzelis valstybes vaizdavo kaip gyvus organizmus ${ }^{62}$, kuriems būdinga augimo tendencija. Ju teritorines sienas ir geografines ribas šis geopolitikas lygino su žmogaus oda, kuri atlieka apsaugines organizmo funkcijas. Informacijos amžiuje valstybès apsaugos funkcijas atlieka ne tiek sienos, kiek jų informacinëje erdvëje susiformavusi dominuojanti pasaulèžiūra - tai informacinis filtras, metakonstrukcija, kuri padeda visuomenei suprasti, atrinkti, rūšiuoti ar atmesti informaciją apie save bei išorinį pasauli. Informacinė geopolitika, pasitelkusi informacinio karo priemones, visu pirma siekia įveikti ši filtrą. Tokiems veiksmams savo tyrimuose daug dẻmesio skyrė Počepcovas ir Rastragujevas. Pirmasis analizavo įtakos efektyvumo problemą ir pabrèžè, kad poveikis iš vidaus visada efektyvesnis už itaką iš išorès ${ }^{63}$.

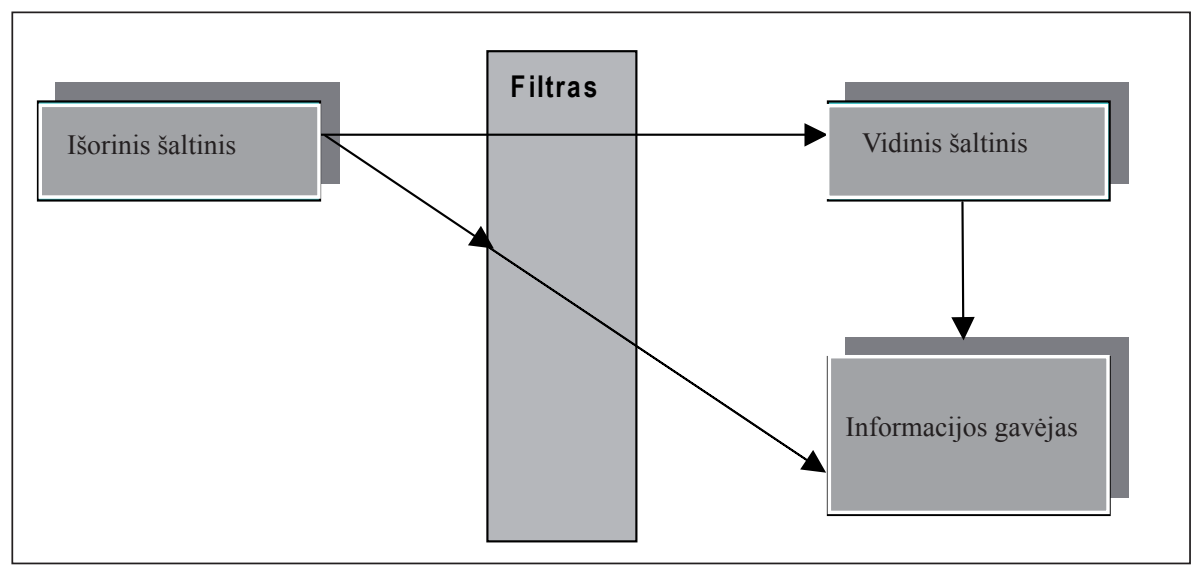

Šaltinis: Georgijaus Počepcovo modelis, kurį Darius Petrošius taiko operatyvinei veiklai, žr. Petrošius D., Informacinis karas ir jo galimybe operatyvinejje veikloje, p. 115.

\section{Schema 4. Informacijos pateikimas apeinant filtra}

Počepcovo modeli galima paaiškinti pasitelkus asmenybės psichologinès apsaugos principa, kai žmogus atsiriboja nuo informacijos, kuri, kaip jis ịsivaizduoja, neatitinka jo vertybinių nuostatų ir gali sugriauti jo asmenybès branduoli. Rusijos informacinio karo ekspertas Jurijus Kolinas teigia, kad

\footnotetext{
62 Дугин (išnaša 40).

${ }^{63}$ Почепцов (išnaša 9), p. 502.
} 
„panašus psichologinės apsaugos elementas egzistuoja ir visuomenëje, kuri, vengdama dezintegracijos, atmeta ir išstumia iš savo kolektyvinès sąmonés nusistovejjusiai pasaulěžiūrai ir nacionaliniam identitetui prieštaraujančią informaciją“ ${ }^{\prime \prime}$. Teigiama, kad toks filtras atlieka visuomenès imuniteto funkciją. Kiekvienoje valstybeje egzistuoja išskirtinès techninės ir kultūrinès konstrukcijos, kuriomis yra įsisąmoninamos žinios, - atsiranda suvokimas. Informacinis karas bando įsiskverbti ir tapti šiu konstrukcijų sudedamaja dalimi, kad galètų daryti įtaką visuomenei iš vidaus.

Toks visuomenės apsaugos mechanizmas tapo Rastragujevo analizès objektu $^{65}$. Šis autorius informacinį karą prilygina informacinei infekcijai ir analizuoja ši reiškinį biologinių, kompiuterinių bei socialinių infekcijų kontekste.

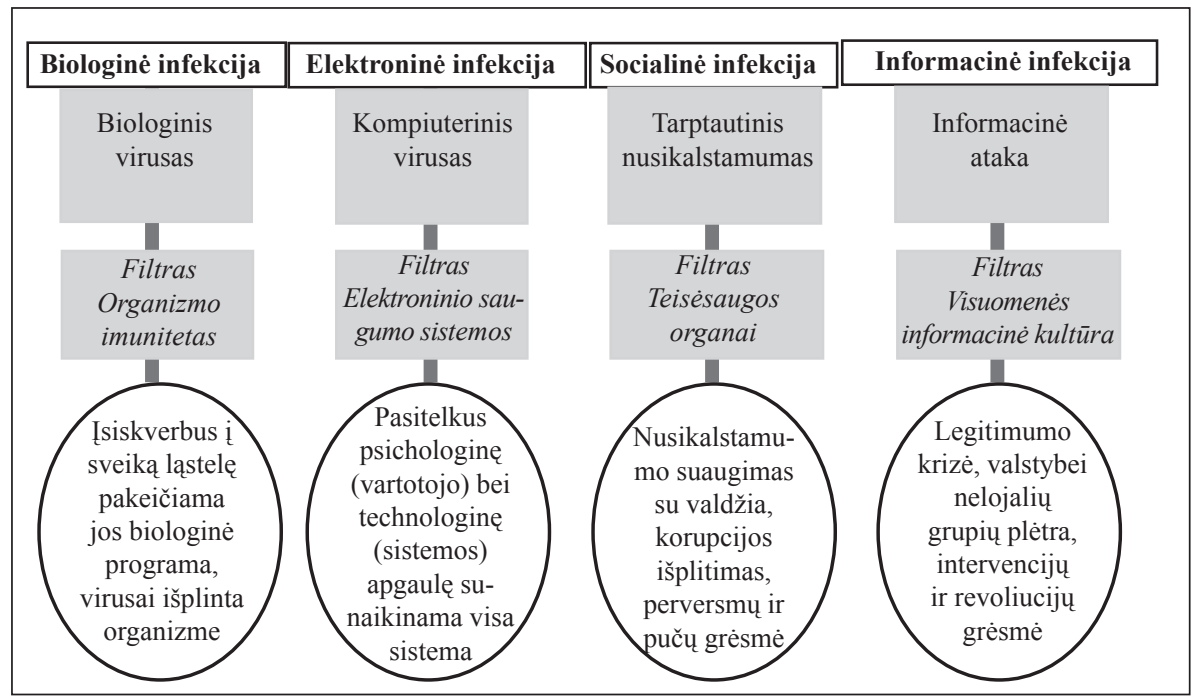

Šaltinis: Modelị autorius sudare pagal Rastragujevo informacinio karo sampratą.

\section{Schema 5. Apsaugos neutralizavimo principas Rastragujevo informacinio karo sampratoje}

Informacinio karo metu visada ieškoma silpnuju visuomenės apsaugos mechanizmo vietu. Tai gali būti didelis visuomenès dezintegracijos laipsnis, istorinès traumos arba valstybès bei atskiru jos elementų (žiniasklaidos, švietimo sistemos ir pan.) silpnumas ir pažeidžiamumas ekonominėmis ar kitokiomis priemonèmis. Informacinis karas taikosi į visuomenès ir valdžios bei visuomenès grupiu tarpusavio santykius siekiant sukelti pasitikejjimo krizę. Počepcovo manymu, kritinè riba kiekvienoje visuomenėje peržengiama tada, kai „daugiau nei 40 proc. žmonių reikalauja radikaliu

\footnotetext{
${ }^{64}$ Колин Ю., „Информационная война: перспективы и стратегии“, Научная мысль Кавказа $\mathrm{Nr} .1$, 2003, http://warning.dp.ua/tel7.htm, 20061102.

${ }^{65}$ Расторгуев С. П., „Инфицирование как способ защиты жизни.“, http://www.koob.ru/rastorguev/virus, 20061102.
} 
politinės sistemos pokyčiu, o centrinės valdžios institutais pasitiki mažiau nei 25 proc. ${ }^{466}$ Šiuo atveju kyla legitimumo krizè bei grèsmè visai valstybės politinei sistemai.

Valstybės informacinès kultūros sampratą analizavusi Daiva Urbonaitė teigia, kad šiuolaikinëje valstybëje egzistuoja išskirtinė informacijos prièmimo ir įsisavinimo struktūra su savo komunikacijos normomis ir taisyklėmis. Ši struktūra atlieka sistemos "sociokultūrinio imuniteto vaidmenị “67. Būtent valstybės informacinę kultūrą galima įsivaizduoti kaip tam tikrą šiuolaikinès visuomenès apsaugos nuo agresyvių informacinès geopolitikos strategiju mechanizmą.

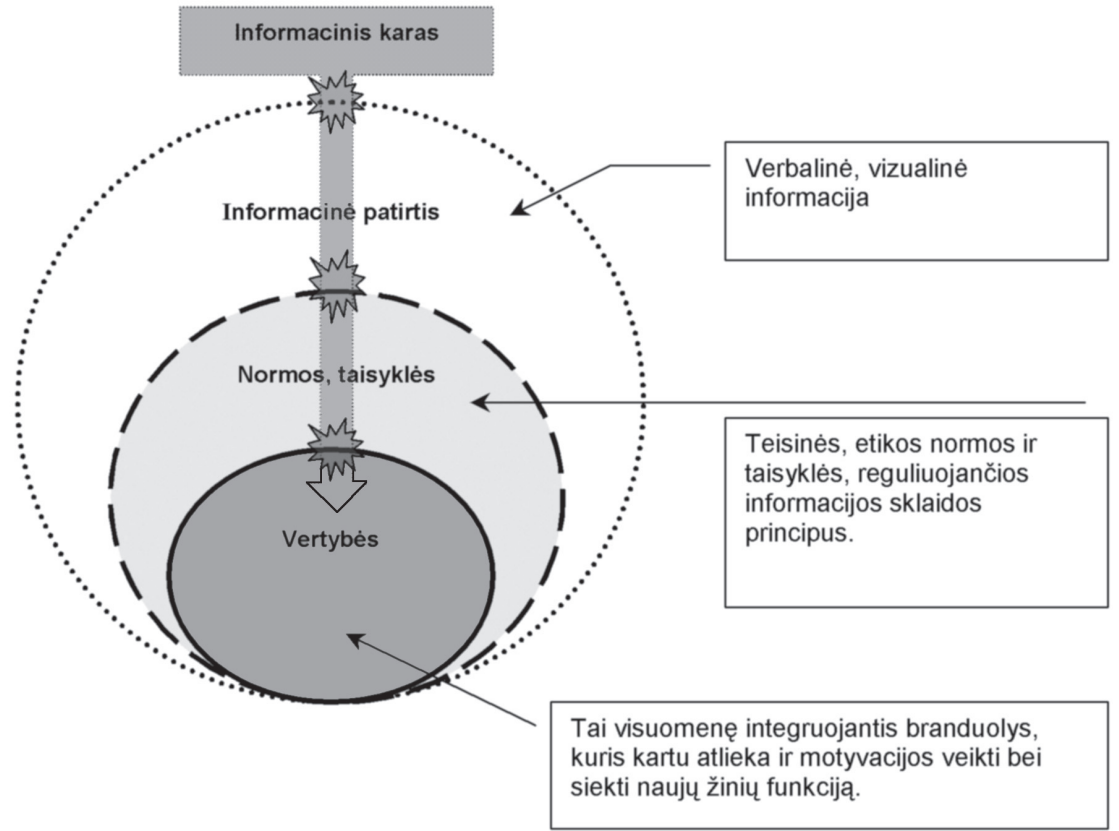

Šaltinis: Modelį autorius sudarè pagal Urbonaitės informacinės kultūros sampratą.

\section{Schema 6. Valstybès informacinè kultūra ir prieš ją nukreiptas informacinis karas}

Websteris taip apibendrina kultūros pokyčius informacijos amžiuje: „Šiuolaikinę kultūrą daug labiau negu bet kurią ankstesnę veikia informacija.

\footnotetext{
${ }^{66}$ Почепцов (ǐ̌naša 9), p. 24

${ }^{67}$ Urbonaitė D., „Informacinès kultūros teorinis pagrindimas“, Informaciniai mokslai Nr. 10, 1999, p. 55.
} 
Gyvename apsupti medijų, o tai reiškia, kad gyvenimas iš esmės yra žinių apie save ir kitus simbolizavimas, ju apykaita arba pasipriešinimas joms ${ }^{\prime \prime 68}$.

Informacinés kultūros branduolys - vertybès (politinès, religinės ir pan.), kurios formuojasi socializacijos proceso metu. Taip visuomenèje įsitvirtina tam tikros vertybės, kurios formuoja motyvaciją siekti tolesnių žinių savo kasdieninei, profesinei ar politinei veiklai. Tačiau informacinès visuomenès vertybiu branduoli supa tam tikros komunikacijos normos ir taisyklès, kurios lemia tai, kaip iš informacinès patirties formuojasi žinios, keičiasi ankstesnès ir randasi naujos vertybès. Šios normos - tai ne tik teisinis žiniasklaidos reguliavimas, bet ir žurnalistu, ryšių su visuomene specialistų, lobistų ar politiniu konsultantu profesinès etikos taisyklès. Urbonaitė teigia, kad vis aktualesnis tampa tam tikras informacinès visuomenès komunikacijos etiketas ${ }^{69}$, t. y. suvokimas, kaip dera elgtis skleidžiant informaciją ir kaip ne. Suprantama, kad šios komunikacijos normos kardinaliai skiriasi demokratinėse ir totalitarinėse visuomenèse.

Kolinas teigia, kad „informacinio karo tikslas yra visuomenès apsaugos mechanizmo sunaikinimas kartu informacinejje erdvèje paskleidžiant su vertybėmis disonuojančią informaciją bei interpretacijas ir taip destabilizuojant visuomenės dvasini, politinį bei ekonomini gyvenimą ${ }^{\prime \prime 70}$. Todèl visu pirma yra išnaudojamos valstybės informacinès kultūros normų, taisyklių bei komunikacijos etiketo spragos. Ypatingas dèmesys skiriamas informaciniu technologiju, telekomunikacijų bei žiniasklaidos rinkos teisinio reguliavimo aspektams. Išnaudojami rinkos dèsniai, kuriems paklūsta žiniasklaida. Plečiamos ekonomiškai motyvuotos informacinės-komunikacinės sistemos.

Reikia pripažinti, kad informacinio karo ir biologinių ar kompiuteriniu virusų analogija yra iš dalies suprastintas požiūris į šią problemą, nes socialiniai ir psichologiniai procesai yra daug sudètingesni už biologinius ar kompiuterinius. Tokia mąstymo paradigma gali vesti prie radikalių teorijų formulavimo ${ }^{71}$. Be to, politikams ir informacinio karo ekspertams gali kilti pagunda spręsti informacinio saugumo klausimus atsiribojimų bei draudimu būdu, kas yra nepriimtina atviroms demokratinèms visuomenèms. Apsauga nuo biologinių ar kompiuterinių virusu yra paprastesnè ir aiškesnè už kompleksinius visuomenès informacinio saugumo sprendimo būdus.

\subsection{Nuo tradicinių manipuliavimo technikų iki „mediageninių krizių“ dramaturgijos}

Počepcovas tegia, kad reklama yra paremta troškimo strategija, ryšiai su visuomene - pasitikèjimo strategija, propaganda - įtikinèjimo strategija, o

\footnotetext{
${ }^{68}$ Webster (išnaša 19), p. 26.

${ }^{69}$ Urbonaitè (išnaša 67), p. 60.

${ }^{70}$ Колин (išnaša 64).

${ }^{71}$, Sidabrinés kulkos “ modelis komunikacijos moksluose arba Pavelo Polujano noovirusu koncepcija.
} 
informacinis karas remiasi rezonanso strategija ${ }^{72}$. Pastarają strategiją galima vadinti rezonansine komunikacija, kai siekiama sudrumsti viešąą erdvę, sukelti ažiotažą, užgožti visą kitą komunikaciją. Tokia strategija nukreipta ne į supratimą ar racionalumą, bet į emocijas ir impulsus. Informacinis karas remiasi trimis esminiais principais:

- Dėmesio atkreipimas.

- Emociju ir jausmų sužadinimas.

- Krizès sprendimo būdu ịpiršimas.

Šiuolaikinėse visuomenėse verslo ar politinės komunikacijos sėkmę lemia tai, ar sugebama atkreipti auditorijos dèmesị i savo informaciją ${ }^{73}$. Informacinio karo priemonemis siekiama sukelti auditorijos emocijas, sukurti nestabilumo jausmą, nepasitenkinimą ir tuo pat metu visuomenei ịpiršti tendencingus dirbtinai sukurtu krizių sprendimo būdus. Informacinio karo metu naudojamos įtakos technikos nėra kažkuo išskirtinės ar absoliučiai originalios. Dažniausiai jos remiasi propagandiniu manipuliavimu, kurị mokslininkai tyrinėjo jau praeito amžiaus pradžioje ${ }^{74}$. Tokia komunikacija remiasi selektyviu politinio, žiniasklaidos elito bei etninių, socialiniu grupių informavimu. Be to, informacija dozuojama, kai pateikiama tik ta dalis faktu, kuri yra naudinga įtaką darančiajam, o apie kitus nutylima. Informacinè agresija remiasi psichologiniu spaudimu - tai savotiškas įsakymas veikti, kažką greitai atlikti, nesuteikiant laiko susimąstyti bei pasinaudoti alternatyviais informacijos šaltiniais. Be to, tokios atakos paprastai remiasi pseudoįvykiais:

„Pseudoįvykis nėra spontaniškas - ji kažkas suplanuoja ir pasodina informacinëje dirvoje. [...] Pseudo įvykis yra kuriamas tam, kad būtų iškart pagarsinamas, tęsiamas, reprodukuojamas ir tiražuojamas ${ }^{\prime \prime 7}$.

Pseudoịvykis nèra realus savo kilme - tai „,mediaįvykis“, kuris sukuriamas žiniasklaidos ir jos dẻka plinta informacinëje erdvejje. Tačiau tokie įvykiai realūs savo pasekmėmis, nes, net ir turẻdami minimalų ryšį su objektyvia realybe, jie šiai realybei daro tiesioginę įtaką motyvuodami visuomenę ar politikus atitinkamiems veiksmams.

Informacinès atakos remiasi žmogaus psichologijos sąlygotu poreikiu suprastinti sudėtingus reiškinius. Taip pasinaudojama egzistuojančiais stereotipais ir mitais. Be to, kuriami nauji, kurie nereikalauja gilios analizès ir racionalaus elgesio motyvavimo, o suteikia tam tikras mąstymo klišes. Informaciniu atakų metu viešoje erdvejje dominuoja būtent tokia informacija, o racionalūs argumentai paverčiami informaciniu triukšmu, nuo kurio visuomenè atsiriboja. Informacinis chaosas neleidžia išsiaiškinti tiesos. Tokia situacija palanki panaudoti net ir absoliutaus melo, kurio dèl informacijos triukšmo nebeįmanoma racionaliai paneigti, techniką.

\footnotetext{
${ }^{72}$ Почепцов (išnaša 9), p. 9-10.

${ }^{73}$ Pastaruoja metu reklamoje ir ryšiuose su visuomene ypač išpopuliarejo domino efekto samprata, žr. http:// www.martinlindstrom.com/, 20061102.

${ }^{74}$ Bernays E. L., Propaganda, New York: Horace Livelight, 1928.

${ }^{75}$ Donskis L., „Gyvenimas pseudoịvykių pasaulyje“, Klaipéda, 20050718.
} 
Informacinio karo metu naudojamas technikas Rusijos informacinès geopolitikos atstovai pateikia kaip originalias, sąlygotas informacijos revoliucijos $^{76}$. Tačiau jas lyginant su dar $1938 \mathrm{~m}$. JAV Propagandos analizès instituto ${ }^{77}$ aprašytais propagandos principais (žr. lentelę 2) atsiskleidžia daug panašumu ir pasikartojimų.

Lentelè 2. Propagandos analizès instituto išskirtos propagandos technikos

1. „Etikečių klijavimas“, kai prieš oponentus naudojamas sarkazmas, jie pašiepiami pasitelkus neigiamus simbolius (name calling - angl.).

2. „Blizgantys apibendrinimai“", kai individams ar ju veiksmams pritaikomos bendro pobūdžio tezès, kurios yra neparemtos irodymais bei racionaliais argumentais (glittering generality - angl.).

3. „Manipuliavimas asociacijomis“, kai neargumentuojant sulyginami teigiami arba neigiami reiškiniai arba savybès (transfer-angl.).

4. „Ekspertų rekomendacijos“, kai ispūdžiui sustiprinti naudojama autoritetinga nuomonè (testimonial - angl.).

5. „Nuo tautos“, kai save bandoma pristatyti kaip paprastą tautos atstovą, o ivyki pateikti kaip visos tautos siekiamybę (plain folks - angl.).

6. „Faktu parinkimas“, kai pateikiama teigiama informacija apie asmeni ar reiškini, bet nutylima neigiama (card stacking - angl.).

7. „Vagono prikabinimas“, kai apeliuojama i žmonių norą elgtis kaip visi, sekti mada (band wagon - angl.).

Šaltinis: Propaganda critic, žr. http://www.propagandacritic.com/.

Naujos įtakos technikos paprastai tėra šių tradiciniu propagandos principu išvestinès. Pavyzdžiui, Manoilo mano, kad elektroninė žiniasklaida sudaro išskirtines salygas geopolitinejje kovoje pasitelkti manipuliavimo technikas, ir jas vardija: tendencingas temu parinkimas; fragmentiškas informacijos pateikimas; manipuliavimas informacijos šaltiniais; informacijos suteikimas tik vienai ar kelioms visuomenès grupèms; nutylëjimas arba nepro-

${ }_{76}$ Žr. Панарин, Информационная война и дипломатия (išnaša 6), p. 222-226.

${ }^{77}$ JAV Propagandos analizès institutą 1937 m. ịkūrẻ socialinių mokslų atstovai, kurie siekè per

visuomenès švietimą neutralizuoti neigiamą propagandos įtaka. 
porcingai didelis eterio laiko suteikimas; logiškai nesulyginamų faktu, reiškinių ar asmenybiu palyginimas; manipuliavimas reportažo kokybe, tendencingai derinant vaizdo ir garso medžiagą; tinkamo konteksto parinkimas arba sukūrimas naujienai arba "kompromatui“; manipuliavimas informacija siekiant sukelti baimès, nepasitikëjimo, pasišlykštejjimo ir pan. emocijas; šališku ekspertu nuomonès pateikimas kaip nešališkos informacijos; manipuliavimas reportažo struktūra, kai nepalankios nuomonès pateikiamos nepatraukliai ir iškraipomos; manipuliavimas sociologinèmis apklausomis ir pan. ${ }^{78}$ Toks klasifikavimas praplečia suvokimą apie galimus įtakos būdus, tačiau idejjiškai atkartoja Propagandos analizės instituto tezes, jas taikant konkrečiai komunikacijos priemonei.

Apibendrindamas visas minètas ir kitų autorių išskiriamas manipuliavimo technikas, Georgijus Gračiovas informacini karą apibrėžia taip: „Tai įtakos menas, kuris skirtas priversti žmones elgtis taip, kaip jie nesielgtu, jei disponuotų tikslia, su įvykiu susijusia informacija“"79.

Tačiau šiuolaikinè žiniasklaida sukūrẻ vieną išskirtinę aplinkybę, kurią informacinis karas siekia žūtbūt išnaudoti. Charlesas Wrightas ją vadina žiniasklaidos disfunkcija: „Šiuolaikinė žiniasklaida turi galią sukelti paniką ir chaosą visuomenëje ${ }^{\prime \prime 80}$.

Komunikacijos teoretikai savo tyrimuose dažnai primena, kokị sąmyši Didžiojoje Britanijoje sukèle Herberto Wellso „Pasauliu karo“ radijo pjesès transliacija ${ }^{81}$. Šiame kontekste labai įdomūs JAV epidemiologo Timothy Joneso tyrimai, kur jis analizuoja šiuolaikinès žiniasklaidos įtaką masinėms „psichogeninèms“ epidemijoms: „Tokią epidemiją galima įtarti, kai visuomenès grupèje pasireiškia simptomai, kuriuos sukelia kažkokia informacija. [...] Aplinkoje klinikiniais tyrimais neaptinkama jokiu organinès ligos sukèlëju [...]. Deja, kol nustatomas masinès psichogeninès epidemijos faktas, ji padaro didžiulę realią žalą bendruomenei ir atskiriems individams" ${ }^{\prime 82}$.

Masinès „psichogeninès" epidemijos katalizatoriumi Jonesas laiko šiuolaikinę žiniasklaidą. Būtent jos dẻka informacinèje erdvèje išryškinami, o vèliau nuolatos eskaluojami bei apibūdinami kokios nors ligos simptomai, kuriuos netrukus pradeda jausti kokia nors žmoniu grupè. Tokios grupès dažniausiai būna atribotos nuo objektyvios informacijos arba ja paprasčiausiai netiki. Jonesą labiau domina medicininiai masinès „psichogeninès“ epidemijos aspektai, tačiau šio autoriaus vardijami pagrindiniai tokio fenomeno principai yra ypač aktualūs informacinio karo kontekste:

- Vienas išskirtinių atributų - gandai, emocionalūs svarstymai, netiksli informacija, kuri užgožia racionalų mąstymą ir realius faktus.

\footnotetext{
${ }_{78}^{78}$ Манойло (išnaša 7), p. 121-122.

${ }^{79}$ Грачев Г. В. „Информационно-психологическая безопасность личности: состояние и

возможности психологической защиты“, РАГС, 1998, http:/www.bookap.by.ru/psywar/grachev/oglav. shtm, 20061102

${ }^{80}$ Macnamara (išnaša 16), p. 3.

${ }^{81}$ Ten pat.

82 Jones T. F., „Mass Psychogenic Illness“, American Family Physician, 200012 15, http://www.aafp. org/afp/20001215/2649.html, 20061102.
} 
- Pažeidžiami labiausiai stresui pasiduodantys individai ir visuomenės grupés.

- Ypač pažeidžiamos uždaros bendruomenės (mokyklos, profesinės, religinès grupès ir pan.).

- Simptomai, apie kurios išgirstama iš žiniasklaidos, yra nesąmoningai imituojami ir atkartojami. epidemiją

- Žaibiškas šio fenomeno plitimo tempas leidžia ji traktuoti kaip

Anksčiau tokie reiškiniai buvo tiriami kaip masinès isterijos ar panikos protrūkiai ${ }^{84}$. Tačiau būtent Jonesas pabrèžè lemiamą žiniasklaidos vaidmenị. Galima teigti, kad žiniasklaida dažniausiai ir tampa masinès „psichogeninès“ epidemijos sukelejju. Rusijos politinis technologas Glebas Pavlovskis, analizuodamas potencialias informacines atakas, užsimena apie Rusijos oponentu siekius „,technogeninès kilmės katastrofas paversti „mediageninėmis“ katastrofomis ${ }^{\text {" }}{ }^{85}$. Toks sąvokos vartojimas yra artimas Joneso samprotavimams.

Taigi galima teigti, kad informacinis karas, išnaudodamas visas tradicinès propagandos technikas, leidžia ne tik subtiliai daryti įtaką geopolitiniu oponentu vidiniams politiniams procesams, bet, pasinaudodamas šiuolaikinès žiniasklaidos ydomis, suteikia galią režisuoti savotiškas masines politines isterijas kitų valstybių informacinèse erdvėse.

\section{Kaip užsitikrinti informacinị saugumą?}

Pastaruoju metu informacinio karo tyrimuose dominuoja techniniai/ fiziniai informacinio saugumo sprendimo būdai. Tai loginè tarptautiniuose santykiuose vis dar dominuojančios realistinès paradigmos pasekmè: „Realpolitik dèsningai reaguoja ị informacinę revoliucija: jai atstovaujantys strategai šiuolaikiniams informacijos ištekliams ir komunikacijos kanalams taiko valstybinio reguliavimo principus, renkasi griežtą apsaugą vietoje atvirumo“"86.

Rastragujevas tokį informacinio saugumo sprendimą vadina ,efektyviu šarvu" strategija ${ }^{87}$. Tokie šarvai gali būti diegiami savo kompiuterinėse sistemose, kaip tai daroma JAV, arba žiniasklaidos struktūrose ar net visose visuomenėse, kaip tai daroma Rusijoje.

\footnotetext{
${ }^{83}$ Ten pat.

${ }^{84}$ Wessely S., „Mass Hysteria: Two Syndromes?“ Psychol Med Nr. 17, 1987.

${ }^{85}$ Павловский (išnaša 51).

${ }^{86}$ Arquilla (išnaša 27) p. 31.

${ }^{87}$ Расторгуев, „Инфицирование как способ защиты жизни“, http://www.koob.ru/rastorguev/virus, 20061102.
} 
Philipas Tayloras pabrěžia, kad „draudimas - tai propagandai analogiška samprata, nes jos abi tèra skirtingos tos pačios monetos, skirtos manipuliuoti viešaja nuomone, pusės “ ${ }^{\text {88 }}$. Technologiniai informacinio saugumo užtikrinimo būdai nepritaikomi demokratiniu informacinių visuomeniu psichologiniam saugumui. Tokią nuostatą galima iliustruoti Henriko Frimano teiginiu. Informacinio karo atveju iškyla klausimas, kaip apsaugoti savo protą? Ši dilema panaši i tą, su kuria susiduria virusu ir „Trojos arklių ${ }^{\prime \prime 9}$ atakuojama kompiuterinè sistema. Tačiau šios problemos reikalauja skirtingų sprendimo būdų. Elektroniniame pasaulyje geriausias saugumo sprendimas - fiziškai išjungti kompiuterị iš virtualaus tinklo. Toks sprendimas absoliučiai netinka visuomenėms, kurios individams būtinos socialinès interakcijos. Šiuo atveju būtina rasti naujų informacijos verifikavimo būdų, kurie padètų neutralizuoti informacines atakas ${ }^{90}$.

Kai kurie komunikacijos mokslų atstovai siūlo pliuralistinius šios problemos sprendimo būdus ${ }^{91}$, ypač šnekant apie žiniasklaidos reguliavimą. Toks požiūris į informacinį saugumą galètų būti prilygintas pagrindiniam energetinio saugumo principui - alternatyvių šaltinių garantijos. Energetikoje tai - natūraliu šaltiniu diversifikacija, o informacinio saugumo atveju - informaciniu bei komunikacinių ištekliu diversifikacija. Taip galia iš informacijos gamintoju ir skleidejuı, t. y. potencialių manipuliuotoju, pereitu i z auditorijos rankas. Tai taptu galia pasirinkti, abejoti, interpretuoti.

Psichologijos ekspertas Everestas Shostromas teigia, kad geriausias priešnuodis nuo manipuliacijos - aktualizacija. Jis melą priešina atvirumui, apatiją - aktyvumui, kontrolę - laisvei; cinizmą - pasitikëjimui ${ }^{22}$. Komunikacijos etiketo formavimas valstybiu informacinëje erdveje taip pat galètu ženkliai prisideti neutralizuojant informacines atakas. Nepakantumas nekorektiškiems informavimo būdams, juodosioms technologijoms ar propagandai galètu niveliuoti ju poveikị atskleidžiant patị manipuliuotoją, jo užslėptus tikslus. Propagandos teorijoje ši technika vadinama šaltinio atskleidimu (source exposure - angl.). Pripažistama, kad vienas svarbiausių įrankiu šiuo atveju tampa žurnalistų, ryšiu su visuomene bei kitų sričių specialistų etikos standartai. Nesigilinant iq atskirus etikos kodeksus, ju panašumus ir skirtumus, tikslinga pristatyti Johano Galtungo požiūrị i i komunikacijos etiką.

\footnotetext{
${ }^{88}$ Taylor M. P., Munitions of the Mind: a History of Propaganda From the Ancient World to the Present Day, Manchester University Press, 1995, p. 10.

${ }^{89}$ Viruso tipas, kuris pažeidžia kompiuterines apsaugos sistemas ir leidžia nesankcionuotai naudotis vidiniais sistemos resursais [N. M.].

${ }^{90}$ Friman H., ,Perception Warfare: a Concept for the Future“, Netherlands Annual Review of Military Studies (NLARMS): Information Operations, ed., Bosch. J. M. J.,Luiijf H. A. M., Mollema A. R., Haveka BV, 1999 , p. 18.

${ }^{91}$ Macnamara (išnaša 16), p. 3.

${ }_{92}^{2}$ Шостром Э., Человек-манипулятор: внутреннее путешествие от манипуляции к актуализации, K.: Psylib, 2003, p. 15.
} 


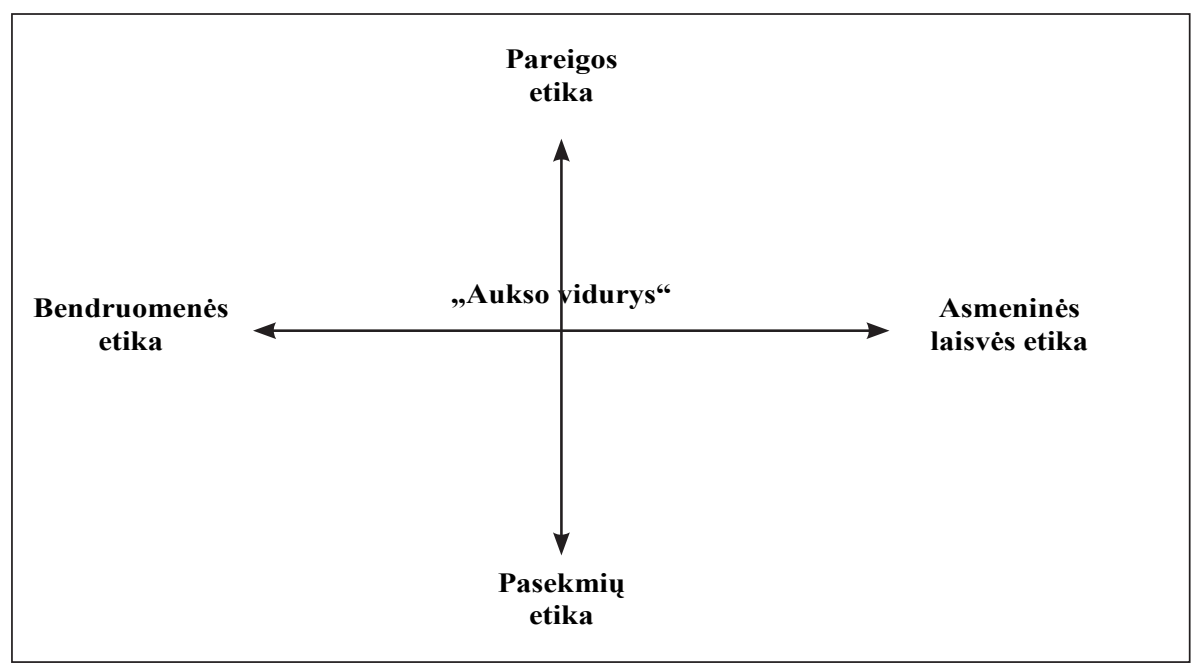

Šaltinis: Johano Galtungo modelis - žr. Galtung, 1999.

\section{Schema 7. Galtungo komunikacijos etikos modelis}

Galtungas ragina siekti ",aukso vidurio" tiek formuluojant profesinius etikos kodeksus, tiek kiekviename su komunikacija susijusiame veiksme. Idealistinis komunikacijos etiketo įtvirtinimo siekis yra nukreiptas į informacijos kūrëjus ir skleidejjus, tačiau egzistuoja požiūriu, kurie akcentuoja pačios auditorijos, t. y. informacijos vartotojų, galimybes užsitikrinti savo informacini saugumą. Austrų elektroninės žiniasklaidos ekspertas Konradas Beckeris atkreipia dėmesị i asmens ir visuomenės kultūrinio išprusimo (cultural intelligence - angl.) laipsnį ${ }^{93}$. Šio autoriaus ịsitikinimu, tokia išprususi visuomenė turètu pati sugebèti atskirti manipuliavimo technikas ir eventualiai i jas nebekreipti dèmesio. Lietuvoje buvo nagrinètas komunikacinių kompetenciju klausimas ${ }^{94}$, tačiau pagrindinis dèmesys čia skirtas ne informacijos dekonstravimo kompetencijai, bet informacijos konstravimo ir siuntimo gebejjimas. Tačiau Beata Grebliauskienè išskyrè ir aktualius mokëjimus priimti informaciją tarpasmeninès komunikacijos metu.

\footnotetext{
${ }^{93}$ Becker K., Cultural Intelligence and Social Control, Vienna: Selene, 2002, p. 69. 
Lentelẻ 3. Komunikacinių mokẻjimų klasifikacija

\begin{tabular}{|c|c|c|c|c|}
\hline \multirow{2}{*}{$\begin{array}{c}\text { Komunikacinės } \\
\text { veiklos tipas }\end{array}$} & \multicolumn{2}{|c|}{$\begin{array}{l}\text { Verbalinès } \\
\text { komunikacijos } \\
\text { mokejjimai }\end{array}$} & \multicolumn{2}{|c|}{$\begin{array}{l}\text { Neverbalinès } \\
\text { komunikacijos } \\
\text { mokèjimai }\end{array}$} \\
\hline & Rašytiniai & Nerašytiniai & Rašytiniai & Nerašytiniai \\
\hline $\begin{array}{l}\text { Mokèjimas } \\
\text { priimti } \\
\text { informaciją }\end{array}$ & $\begin{array}{l}\text { Mokèjimas } \\
\text { skaityti } \\
\text { „tarp } \\
\text { eilučiu“. }\end{array}$ & $\begin{array}{l}\text { Mokèjimas } \\
\text { girdèti ir } \\
\text { atpažinti } \\
\text { verbalinę } \\
\text { kalbą, skirti } \\
\text { intonacijas. }\end{array}$ & $\begin{array}{l}\text { Mokèjimas matyti ir } \\
\text { atpažinti: } \\
\text { - simbolius; } \\
\text { - teksto sutvarkyma;; } \\
\text { - nuotraukas ir t. t. }\end{array}$ & $\begin{array}{l}\text { Mokėjimas matyti ir } \\
\text { atpažinti: } \\
\text { distancija, } \\
\text { pozas, } \\
\text { gestus, } \\
\text { akių kontaktą ir t. t. }\end{array}$ \\
\hline
\end{tabular}

Šaltinis: Grebliauskienė B., „Komunikacinių mokëjimų struktūra ir turinys“, Informacijos mokslai Nr. 7 (2), 1997, p. 52.

Taigi komunikacinè kompetencija galètų būti apibrèžiama kaip gnostinis bei operacinis-techninis gebejjimas dalyvauti komunikacijos procese $\mathrm{e}^{95}, \mathrm{t}$. y. mokejjimas generuoti informaciją (mintį), ją užkoduoti, perduoti, priimti grịžtamajį ryší, dekoduoti gaunamą informaciją (mintị) bei ją suprasti. Minèta autore analizuoja bendras komunikacines kompetencijas, tačiau neišskiria gebëjimo priimti informaciją iš šiuolaikinès žiniasklaidos (ypač elektroninės) priemonių. Tokią kompetenciją, pasiskolinus kompiuterinio raštingumo terminą, galima būtų vadinti „žiniasklaidos raštingumu“. Dabar visuotinai pripažistama, kad kiekvienam informacinès visuomenès nariui yra būtinas sugebejjimas naudotis kompiuteriu bei informacinèmis technologijomis. Todèl ir "žiniasklaidos raštingumo“ formavimas valstybès informacinëje kultūroje turètų tapti vienas iš pagrindinių uždavinių, siekiant visuomenę išmokyti gyventi „mediarealybės“ sąlygomis ir neutralizuoti informacinio karo atakas.

Tenka pripažinti, kad toks pliuralistinis požiūris į informacini saugumą yra pažeidžiamas jau aptartomis informacinio karo technikomis diskredituojant racionalius argumentus arba jų skleidejjus. Tačiau susižavëjimas draudimo ir informacijos reguliavimo metodais gali kelti grèsmę atviroms demokratinėms visuomenèms. ${ }_{95}^{95}$ Grebliauskienė B., „Komunikacinių mokèjimu struktūra ir turinys“, Informacijos mokslai, nr. 7 (2), 1997,
p. 46. 


\section{Išvados}

Lietuva, būdama modernios geopolitinès erdvės dalimi, drauge daro įtaką šiai erdvei ir patiria jos spaudimą. Svarbu suvokti, kaip, bandydama išlaikyti savo įtaką posovietinejje aplinkoje, informacinius galios svertus naudoja Rusija.

Kai kurie Rusijos informacinès geopolitikos bei informacinio karo tyrinètojai (Igoris Panarinas, Georgijus Počepcovas ir kt.) aktyviai dalyvauja kuriant bei igyvendinant užsienio politikos strategijas posovietinejje erdvëje ${ }^{96}$. Tokia situacija tik dar kartą patvirtina ypač glaudų Rusijos geopolitinių teoriju santykị su politikos praktika. Todèl pristatytas teorinis požiūris į informacinės geopolitikos ir informacinio karo sampratas turètu prisidèti prie praktiniu Rusijos politikos tyrimų.

Taip pat būtina atkreipti dèmesị i tai, kad didžioji dalis informacinio karo tyrimų užsienyje ir Lietuvoje koncentruojasi ị jo priemones, manipuliavimo technikas arba analizuoja informacinių sistemu pažeidžiamumo problemas. Tačiau retai keliamas informacinio karo ir moralès santykio klausimas. Ateityje Lietuvoje būtina šį reiškinį analizuoti teisès ir komunikacijos etikos kontekste. Tai sudarys sąlygas rekomenduoti atvirai demokratinei visuomenei priimtinas ir efektyvias informacinio saugumo priemones.

Vilnius, 2006 m. spalis - gruodis

${ }^{96}$ Minèti autoriai yra prieštaringai vertinamo forumo „Europa“ nariai, žr. http://europeforum.info/users/ ?user_session=6723ae06a71de0fc0b027e8f4a931884, 20061102. 